\title{
Humanitarian Considerations in International Air Law
}

\author{
Laura Wanlu Zhang*
}

\begin{abstract}
The downing of civil aircraft over conflict zones presents serious challenges for current international air law, especially regarding powers and responsibilities of public and private entities. Considering the extensiveness of areas experiencing current hostilities, the question of whether public or private entities should take responsibility following such accidents has become a highly topical issue. Under Article 9 of the Chicago Convention, States exercising complete and exclusive sovereignty over their territory are allowed the right to close their flight-paths. Consequently, a critical question arises as to whether States are obliged to close their airspace during times when their territories endure ongoing armed conflicts. In this author's view, the problem results from the varying perceptions concerning fragmentation within the international law system. To protect the safety of civilians in the sky, this article scrutinises the legality of allowing open airspace over conflict zones. It questions the role of 'elementary considerations of humanity' in order to draw closer towards a potential harmonisation between the secondary rules of special regimes-air law and humanitarian law.
\end{abstract}

\section{Keywords}

Use of Airspace, Conflict Zones, Humanity

* Ph.D. Candidate, the International Institute of Air and Space Law, Universiteit Leiden. Comments may be addressed to w.zhang@law.leidenuniv.nl. I wish to thank Leah Powell for her valuable assistance with regard to language. Helpful comments were provided by Roderick van Dam, Professor Pablo Mendes de Leon, Dr. Jiefang Huang, and Professor Mia Wouters. Any errors are of course my own. 


\section{Introduction}

On 17 July 2014, flight MH17 from Amsterdam to Kuala Lumpur was downed in the territory of eastern Ukraine controlled by hostile groups. ${ }^{1}$ Afterwards, an investigation $^{2}$ was carried out pursuant to International Civil Aviation Organisation (ICAO) Annex 13 which states that ' $\mathrm{t}$ ] he sole objective of the investigation of an accident or incident shall be the prevention of accidents and incidents. It is not the purpose of this activity to apportion blame or liability.' Therefore, this paper will not probe into who might be the perpetrator, but will instead endeavour to clarify the legal issues regarding the safe use of airspace over conflict zones in order to prevent similar accidents from taking place.

To analyse this issue, the paper will begin by setting out the law. Rules with respect to aviation risks within conflict zones are much more comprehensive than one might infer from the discussions of military strategists and political scientists. The reason for this is that, in reality, accidents never occur in such a way that they can fit comfortably into the application scope of a single branch of international law. Those branches are established by dividing international rules for the convenience of scholars. As a result, the range of applicable legislation could be considered in the following five categories:

(i) The lex specialis - the Chicago Convention on International Civil Aviation and its Annexes which relate specifically to the use of airspace. ${ }^{4}$

(ii) The international law applicable generally to armed conflicts-the jus in bello, often referred to as the 'international humanitarian law'.

1 Matthew Weaver and Shaun Walker, 'MH17: Dutch to Unveil Official Crash Report' The Guardian (London, 13 October 2015) <http://www.theguardian.com/world/2014/dec/25/ mh17-russia-claims-to-have-airfield-witness-who-blames-ukrainian-pilot> accessed 14 May 2016.

2 Dutch Safety Board, Crash of Malaysia Airlines Flight MH17 (The Hague, October 2015) <http://www.safetyboard.nl> accessed 15 May 2016. International Civil Aviation Organisation, Annex 13 to the Convention on International Civil Aviation, Aircraft Accident and Incident Investigation, para 3.1.

4 Convention on International Civil Aviation (adopted 7 December 1944, entered into force 4 April 1947) 15 UNTS 295 (the Chicago Convention). Its Annexes can be found on <http:// www.icao.int/safety/safetymanagement/pages/sarps.aspx> accessed 11 October 2016. 
(iii) The international human rights law-all fundamental freedoms and all basic social, economic and cultural rights provided to each individual independent of nationality. ${ }^{5}$

(iv) The entire corpus of international law that governs State obligations and rights generally, which may affect airspace policy in particular circumstances.

(v) National/regional law, both constitutional and statutory, which may apply to decisions on airspace by national authorities.

All of these will be addressed in the ensuing discussion, and the focus will be to reconcile rules relating to the use of airspace by clarifying the confusion caused by the fragmentation within international law. The international community has made great efforts to address this issue. During the ICAO $203^{\text {rd }}$ Council Session in 2014 and ICAO High-Level Safety Conference in February 2015, it was concluded that ' $\mathrm{s}$ ] tates continue to have the responsibility to ensure the safety of operations in their sovereign and delegated airspace; and airspace users have the ultimate responsibility to decide where they are able to operate safely. ${ }^{6}$ Therefore, airspace users, airlines and passengers, are imposed with 'ultimate responsibility'. However, this is far from practical when one considers the power conferred on States and airspace users respectively. This paper begins with an assessment of whether the decisive power concerning flight-paths should be controlled by public or private power. On the public side, there are State and air traffic control agencies ${ }^{7}$ that may

Robert Kolb and Gloria Gaggioli (eds), Research Handbook on Human Rights and Humanitarian Law (Edward Elgar 2013) 3; Further, the International Court of Justice observes that the protection of human rights law does not cease in times of war, see Legality of the Threat or Use of Nuclear Weapons (Advisory Opinion) [1996] ICJ Rep 226, para 25 ('Nuclear Weapons').

6 ICAO, 'Task Force on Risks to Civil Aviation Arising from Conflict Zones, Appendix A, Chairman's Report' (8 September 2014) C-WP/14220 para 2.1; ICAO, 'Sharing Information on Risks to Civil Aviation Arising From Conflict Zones' (2 January 2015) HLSC/15-WP/13 para $2.1<\mathrm{http} / /$ www.icao.int/Meetings/HLSC2015/Lists/WorkingPapers/DispForm.aspx?ID=48 \&ContentTypeId=0x0100A6F97857FE53F64A97ABE90D99F972A4> accessed 14 May 2016. In addressing activities relating to Air Traffic, the most important ones are:

- Air Traffic Management (ATM) encompasses the functions needed to ensure safe and efficient movement of aircraft during all phases of operation: air traffic services, airspace management and air traffic flow management;

- Air Traffic Services (ATS), which is a part of ATM, is a generic term meaning variously flight information service, alerting service, air traffic advisory service and air traffic control service; and

- Air Traffic Control (ATC) is a service operated by the appropriate authority to promote the safe, orderly and expeditious flow of air traffic. 
sometimes be corporatised or even privatised; while the private side consists of airspace users, airlines and passengers.

\section{The public and private power divide}

Put simply, the most specific and relevant rules relating to the present problem can be found in the Chicago Convention. For example, Article 1 of the Chicago Convention recognises that every State has 'complete and exclusive' sovereignty over the airspace above its territory. Therefore, this denotes that the State is the only legitimate and competent entity to collect safety intelligence regarding conflicts in its territory; in contrast, airspace users can only relay national authorities' information to make decisions.

Notably, in terms of privatised Air Traffic Control, it is necessary to clarify that they belong to the domain of public power because their conduct can be attributed to the State. Firstly, according to Article 28 of the Chicago Convention, States have the obligation to provide an air navigation service, meaning that it is an inherently public function. Secondly, according to customary international law that is enshrined in the Articles on Responsibility of States for Internationally Wrongful Acts (ASIWA), the conduct of an individual shall be considered an act of a State if the person in fact acts on the instructions of, or under the control of, that State. ${ }^{8}$ Air traffic control agencies performing these public functions are exercising government power, and therefore, their conduct shall be attributed to the State. The jurisprudence of the Überlingen collision case has effectively confirmed this point. In this particular case, an accident occurred in German airspace and the air navigation services were provided by a Swiss-based company. The court ruled

See David McMillan and Roderick van Dam, 'EUROCONTROL and the EU Single European Sky' in Daniel Calleja Crespo and Pablo Mendes de Leon (eds), Achieving the Single European Sky: Goals and Challenges (Kluwer 2011) 67-68 ('Single European Sky').

8 ILC, 'Draft Articles on Responsibility of States for Internationally Wrongful Acts, with Commentaries' (2001) II(2) Ybk ILC 26, 38-40; It refers to the case concerning the difference between New Zealand and France regarding the interpretation or application of two agreements concluded on 9 July 1986 and which related to the problems arising from the Rainbow Warrior (New Zealand v France) (1990) 82 ILR 499; See also Ruwantissa Abeyratne, 'State Liability for Negligent Acts of Autonomous Air Navigation Service Provider' (2006) 22 Professional Negligence 176, 183-92. 
that responsibility exclusively rested upon Germany on the grounds that air traffic control is a sovereign task and it must be performed by State authorities. ${ }^{9}$

Moreover, regarding the judgment of the Cagliari collision case, ${ }^{10}$ the traffic controllers, considered to be the 'guarantors' of aviation safety, have the obligation proactively to eliminate the risky elements of the flight-plan once they notice that an aircraft is in a 'dangerous' situation. ${ }^{11}$ The Court took the view that failing to prevent an incident where the traffic controllers had a legal obligation to do so is equivalent to causing it with culpability. ${ }^{12}$ According to State practice, national authorities are the only reliable provider of intelligence upon which the potential risks over certain areas are assessed. ${ }^{13}$ The very purpose of reducing aviation risks is to deliver safe flights, which could help to connect countries with one another. This process requires support from States for a specialised technical management of air traffic flow. The government involvement in aviation safety supervision ensures that only public power will be able to make reasonable decisions on whether it is safe enough to fly over certain areas. In conclusion, allocating the decisive power to the public sphere is both legally sustainable and practically viable, and the ultimate responsibility should rest upon States rather than airspace users.

The orginal text is: 'Flugsicherung und Luftaufsicht gem. $\$ \$ 27 c, 29$ Abs. 1 LuftVG obliegen, wie oben ausgeführt,der Beklagten innerhalb ihres Staatsgebietes als hoheitliche Aufgabe'. Landgericht Konstanz, Bashkirian Airlines v Bundesrepublik Deutschland (27 July 2006) 48.

10 On 24 February 2004, a Cessna 550 inbound to Cagliari at night requested and was approved for a visual approach without crew awareness of the surrounding terrain. It was subsequently destroyed by terrain impact and all on board were killed. The Investigation concluded that the accident was mainly because the crew lacked adequate visual references. The Final Report of the investigation published on 1 July 2009 was not made available in English translation but an unofficial and partial translation into English may be found on <http://www.skybrary.aero/ index.php/C550,_vicinity_Cagliari_Sardinia_Italy,_2004> accessed 8 January 2015.

11 Carmelo Starrantino and Marcello Finocchiaro, 'The 2004 Cagliari Accident and Afterwards: The Judicial Aftermath' (2013) 18 Hindsight Winter 70, 76.

12 ibid 76-77; Also in Öneryildiz v Turkey, the ECtHR adjudge and declare the State is held responsible even if the victim has knowingly chosen to live in the vicinity of a dangerous area. The Court held that '[i]t was the public authority's default in observing the law that precipitated and induced the subsequent default by the individual (...) It would be hard for the Government to maintain legitimately that any negligence or lack of foresight should be attributed to the victims of the accident'. See Öneryildiz v Turkey (2005) 41 EHRR 20, paras 103-06.

13 For instance, in Europe, the function of European Aviation Crisis Coordination Cell (EACCC) relies on information provided from National Focus Point. See Eurocontrol, 'The EACCC: Coordinating Europe's Crisis Response' <http://www.eurocontrol.int/articles/europeanaviation-crisis-coordination-cell-eaccc $>$ accessed 3 March 2016. 


\section{The legality of use of airspace over conflict zones}

Having clarified the rules relating to the divide of public and private power in airspace usage, this paper will now turn to the more specific issue of allowing open airspace over conflict zones.

\subsection{Current international law rules}

This paper will first address the question of whether there are specific rules within international law concerning the legality of airspace usage over conflict zones per se. It will then examine the question at hand in light of the law applicable in armed conflicts proper, ie, the principles and rules of humanitarian law applicable in armed conflicts.

\subsubsection{International air law}

Article 9 of the Chicago Convention declares that States may, 'for reasons of military necessity or public safety, restrict or prohibit uniformly the aircraft of other States from flying over certain areas of its territory. The permissive language of Article 9 is in line with a State's sovereignty over its airspace as specified in Article 1 of the Chicago Convention. ${ }^{14}$ States have the right to decide whether or not to use certain

14 During ICAO Special Group's Meeting on Reviewing the Application of ICAO Treaties Relating to Conflict Zones in Montreal from 13 to 15 July 2015, one delegation recalled the permissive language of Article 9 and proposed to replace the word 'may' with 'shall' in order to clearly establish the responsibility of States with regard to the risks posed by military or other hazardous activities. But other delegations remarked that the permissive language of the Article correctly reflected a State's sovereignty over its airspace as specified. In the end, most States agree that sovereignty is the stepping stone of the Chicago Convention. Therefore, States have the 'freedom' to establish any restrictions to their own airspace, and the word 'may' in Article 9 should be kept as it is. However, for the problems exposed, some delegations stressed the solutions are to develop guidance materials, such as Cir.330 and Doc.9554 to de facto improve the oversight of safe use of airspace. See ICAO, 'Special Group to Review the Application of ICAO Treaties Relating to Conflict Zones' (18 September 2015) SGRIT-CZ/1 Draft Report, paras 2.6-2.9. 
airspace at their own discretion. ${ }^{15}$ Until now, the legality of allowing open airspace over conflict zones has not been addressed by the Chicago Convention.

\subsubsection{International humanitarian law}

This paper will examine other disciplines of international law with the minimum degree of detail necessary to attract further considerations. It is noted that international customary and treaty law does not contain any specific prescription authorising the use of airspace over conflict zones for civil aviation. However, nor is there any principle or rule of international law which would make the legality of airspace usage dependent on a specific authorisation. Such legality does not result from an absence of authorisation but, on the contrary, is formulated in terms of prohibition.

Therefore, it is imperative to examine whether there is any prohibition or suspension of flight over conflict zones. As such, it is first important to identify whether there is a conventional prescription to this effect.

As the prevailing regime governing armed conflicts, established humanitarian rules have a very ancient lineage spanning thousands of years. Through the ages, many civilisations have contributed to the mould in which modern humanitarian law has been formed, revealing the effort of the human conscience to mitigate the brutalities and dreadful sufferings created by armed conflicts. ${ }^{16}$ This body of fundamental principles exists in addition to over 600 specific provisions within the four Geneva Conventions and their Additional Protocols. It is thus a crucial body of law in its own right, and this new aviation case in a sense puts it to the test.

Normally, a humanitarian law application starts with discussing whether the armed conflict is international or non-international, assessing to what extent foreign support could escalate an internal armed conflict, and deciding whether Protocol Additional to the Geneva Conventions of 12 August 1949, and relating to the Protection of Victims of International Armed Conflicts (AP I) ${ }^{17}$ or Protection 2014) 13-45.

16 Nuclear Weapons (n 5) 443 (Dissenting Opinion Judge Weeramantry).

17 Protocol Additional to the Geneva Conventions of 12 August 1949, and relating to the Protection of Victims of International Armed Conflicts (Protocol I) (adopted 8 June 1977, entered into force 7 December 1978) 1125 UNTS 3 ('AP I'). 
of Victims of Non-International Armed Conflicts (AP II) ${ }^{18}$ should apply. The significance of such typology lies with the grant of 'combatant status' and prisoner of war (POW) treatment as well as international rights and obligations deriving from the classification. ${ }^{19}$ However, this is of less pertinence in the present case, since this paper focuses on the protection of passengers on a civil aircraft, and arguably, they deserve protection in either scenario. Specifically, such protection is crystallised in Article 58 of AP I, which provides for additional precautions to be taken. ${ }^{20}$ This article expresses a general obligation under customary international law to protect civilians against widespread and devastating damage which may be expected to cause the loss of civilians.

In addition, in order to examine customary international law and determine whether limitations of airspace usage over conflict zones flow from the said source of law, this paper then looks 'primarily in the actual practice and opinio juris of States. ${ }^{21}$ It is clear that a number of States adhere to the practice of advising their airlines not to fly over conflict zones. Major airlines, including all US commercial airlines, British Airways, Qantas and Cathay Pacific had been avoiding Ukrainian

18 As lex specialis applicable to non-international armed conflicts, 'AP II' (Protocol Additional to the Geneva Conventions of 12 August 1949, and relating to the Protection of Victims of Non-International Armed Conflicts (Protocol II) (adopted 8 June 1977, entered into force 7 December 1978) 1125 UNTS 609) ('AP II') has a much higher threshold. The threshold can be found in Part I of APII, which Ukraine has ratified. Due to the lack of evidence, it is not possible to check if all the preconditions are fulfilled. The author was present at the briefing meeting on MH17 accident investigation given by Dutch Safety Board in ICAO headquarters on November 6, 2015. There were rebuttals to the validity of key evidence and no international consensus on this issue was ever reached.

19 There is a distinction between international armed conflicts and non-international armed conflicts (and within non-international armed conflicts, the difference between Common Article 3 and AP II conflicts with their different thresholds). The treaty law is very different and, despite the attempts of the ICRC and the ICTY, even the customary law has key differences. See, for instance, Jelena Pejic, 'Unlawful/Enemy Combatants: Interpretations and Consequences' in Michael Schmitt and Jelena Pejic (eds), International Law and Armed Conflict: Exploring the Faultlines: Essays in Honour of Yoram Dinstein (Martinus Nijhoff 2007) 335-57; Horst Fischer, 'Protection of Prisoners of War' in Dieter Fleck (ed), The Handbook of International Humanitarian Law (2nd edn, OUP 2008) 396-411.

20 Article 58 of AP I is titled 'Precautions Against the Effects of Attacks' (emphasis added).

21 Continental Shelf (Libyan Arab Jamahiriya v Malta) (Judgment) [1985] ICJ Rep 13, para 27. 
airspace for months before the downing of MH17 after receiving a Notice to Airmen (NOTAM). ${ }^{22}$

With respect to opinio juris, its existence may be proved by UN General Assembly Resolutions which may have normative value, especially those in certain formulations that contain the term 'should. ${ }^{23}$ General Assembly Resolution 2444 (XXIII) and Resolution 2675 (XXV) reinforced the general view that every effort should be made to spare civilian populations from the ravages of war, and all necessary precautions should be taken to avoid injury, loss or damage to civilians. ${ }^{24}$ These expressions amount to a confirmation of customary law relating to precautionary measures in armed conflicts.

Further, the International Criminal Tribunal for the former Yugoslavia (ICTY) stated in the Kupreškić case: 'each party to the conflict, to the extent feasible, to remove civilian persons and objects under its control from the vicinity of military objectives in both international and non-international armed conflicts. ${ }^{25}$ Addressing the reality that AP I is not yet binding on all States in its entity, the tribunal declared that these principles spelled out in Article 58 are now part of customary international law. ${ }^{26}$ In view of this, as a corollary of the principle of distinction between civilian and military targets, ${ }^{27}$ the airspace usage over conflict zones is compromised by the obligation under international law to take precautionary measures.

These obligations are powerful constraints for all the States having subscribed to the cause of maintaining peace and security. Notably, in the present case of flight over conflict zones, civilians are on board an aircraft and from third States. The legal significance of this is that they deserve special, arguably higher, protection

The NOTAM reads: FDC 4/2182 (A0025/14)-null AIRSPACE SPECIAL NOTICE UKRAINE POTENTIALLY HAZARDOUS SITUATION -SIMFEROPOL (UKFV) AND DNEPROPETROVSK (UKDV) FLIGHT INFORMATION REGIONS (FIR). See also Rupert Neate and Jessica Glenza, 'Many Airlines Have Avoided Ukrainian Airspace for Months' The Guardian (London, 18 July 2014) <http://www.theguardian.com/world/2014/jul/18/airlinesavoid-ukraine-airspace-mh17> accessed 14 May 2016. Nuclear Weapons (n 5) para 70. UNGA Res 2444 (XXIII) (19 December 1968), UN Doc A/7218 (adopted unanimously with 111 votes); UNGA Res 2675 (XXV) (9 December 1970), UN Doc A/RES/2675 (adopted by 109 votes in favour; none against and 8 abstentions). Prosecutor $v$ Kupreškić et al (Trial Judgment) ICTY-95-16-T (14 January 2000) para 524 ('Prosecutor v Kupreškic'). ibid.

27 Rules 1 and 7, cited in Jean-Marie Henckaerts and Louise Doswald-Beck (eds), Customary International Humanitarian Law (CUP 2005). 
than those civilians on ground. The reason is that by no means can passengers on a civil aircraft 'directly participate ${ }^{28}$ in conflicts as well as the fact that they cannot be associated with any 'military advantage anticipated.'

The commitments set out in humanitarian instruments lead to the security assurances given by the international community to civilians. These treaties bear witness to the recognition of a rule on precautionary measures. These jurisprudences confirm that the humanitarian obligation requires the application of certain control and restriction to the use of airspace. It seeks to protect civilians from the expansion of armed conflicts where airspace is used in a negligent manner.

The compromise of subjecting airspace management to civilian protection is also consistent with general principles of international law. In the famous Corfu Channel case, which involved British ships that struck mines in Albanian waters, the perpetrator who had laid the mine remained unknown and Albanian knowledge of the mine was abstract, yet its responsibility was nonetheless established. The court reckoned that the obligation to disclose the existence of a minefield and warn approaching British warships was based on 'elementary considerations of humanity. ${ }^{30}$

The Corfu Channel statement is significant in two particular ways. First, it takes note of the need to safeguard the safety and security of transportation. ${ }^{31}$ Second, it highlights the importance of a general norm in respect of human protection. At the time when the UN Charter had just entered into force and no human rights law regime was in place, such 'considerations of humanity' were in fact 'related to human values already protected by positive legal principles which, taken together, reveal certain criteria of public policy and invite the use of analogy. ${ }^{32}$

31 The Corfu Channel doctrine was later reiterated and developed in the law of the sea cases, eg, The $M / V$ 'Saiga' (No. 2) Case (Saint Vincent and the Grenadines v Guinea) (Merits) [1999] ITLOS Rep 10, para 155 ('Saiga'); The 'Juno Trader' Case (Saint Vincent and the Grenadines $v$ Guinea) (Merits) [2004] ITLOS Rep 17, para 77; Maritime Boundary Arbitration (Guyana v Suriname) (2007) 139 ILR 566, para 405; The Arctic Sunrise Arbitration (Netherlands v Russia) (2015) 55 ILM 1, para 191.

32 Ian Brownlie, Principles of Public International Law (7th edn, OUP 2008) 27. 
Notably, the phrase 'elementary considerations of humanity' is echoed and emphasised in subsequent domestic and international decisions. ${ }^{33}$ It was invoked in humanitarian, environmental, human rights and maritime law cases. ${ }^{34}$ This established the basis of what some consider to be a constitutionalist, value-oriented formulation of international law. ${ }^{35}$

However, the connotation of 'elementary considerations of humanity' is not unequivocal. Those seeking further enlightenment as to the nature and status of the principle or how the judges reached their conclusion in the Corfu Channel case find little assistance in the judgements or arguments put to the ICJ. ${ }^{36}$ In other tribunals, decisions can vary in what exactly those 'considerations of humanity' are as well as their legal implications. For some judges, the expression is considered to be indicative of fundamental human rights and dignity, serving the purpose of protecting individuals. ${ }^{37}$ However, others seemed to consider it as a matter that Christakis and Sarah Heathcote (eds), The ICJ and the Evolution of International Law: The enduring impact of the Corfu Channel case (Routledge 2012) 264.

ibid 22; Military and Paramilitary Activities in and against Nicaragua (Nicaragua $v$ USA) (Merits) [1986] ICJ Rep 14, para 215; Nuclear Weapons (n 5) para 79; Prosecutor v Kupreškić (n 25) para 524. Especially, in Husayn (Abu Zubaydah) v Poland, the European Court of Human Rights held that Poland violated Articles 3, 8 and 13 of the European Convention of Human Rights because Poland made no attempt to prevent those violations of human rights from happening: see Husayn (Abu Zubaydah) v Poland App no 7511/13 (ECHR, 24 July 2014) 876; See also Osman v UK (2000) 29 EHRR 245, para 116; $Z$ and Otherrs $v$ UK (2002) 34 EHRR 97, para 73; Velásquez Rodriques $v$ Honduras (Merits) IACtHR Series C No 4 (29 July 1988) paras 172-75; Helen Duffy, The 'War on Terror' and the Framework of International Law (2nd edn, CUP 2015) 472-73, 804; Sandra Krähenmann, 'Positive Obligations in Human Rights Law During Armed Conflicts' in Robert Kolb and Gloria Gaggioli (eds), Research Handbook on Human Rights and Humanitarian Law (Edward Elgar 2013) 170. Zagor (n 33) 264.

36 ibid 266; As to the doctrine's place in the topology of international law sources, there has been quite voluminous discussion, eg Fitzmaurice aligned 'an obligation to act in accordance with elementary considerations of humanity' in the context of discussing 'general principles of good conduct', see Gerald Fitzmaurice, 'The Law and Procedure of the International Court of Justice: General Principles and Substantive Law' (1950) 27 BYIL 4; Michael Akehurst, 'Equity and General Principles of Law' (1976) 25 ICLQ 801; Martti Koskenniemi, 'The Pull of the Mainstream' (1990) 88 Michigan LR 1946; Humphrey Waldock, 'General Course on Public International Law' (1962) 106 Recueil des Cours de l'Académie de Droit International 63; Francesco Francioni, 'International "Soft Law": A Contemporary Assessment' in Vaughan Lowe and Malgosia Fitzmaurice (eds), Fifty Years of the International Court of Justice: Essays in Honour of Sir Robert Jennings (CUP 1996) 169; Fabián Raimondo, 'The International Court of Justice as a Guardian of the Unity of Humanitarian law' (2007) 20 LJIL 593. Saiga (n 31) para 20 (Separate Opinion Judge Mensah). 
underpins the lex lata, yet at the same time, a matter which leads to a more humanoriented lex ferenda. ${ }^{38}$ Importantly, the background behind both schools of thought is that these 'considerations of humanity' were invoked solely by individuals against allegedly unlawful action exercised by the State. ${ }^{39}$ This is the anchor point at which the present issue of airspace usage can relate to considerations of humanity. Considering the contentious and ever-lasting debate over the nature and application of these 'considerations of humanity', this paper will not endeavour to further elaborate on its normativity, but rather argue that this formulation may offer the idea that it is not impossible for air law discussions to take humanitarian law into account.

\subsection{Re-examination of the doctrine of lex specialis}

As has been demonstrated, international law has evolved into a sophisticated yet fragmented ${ }^{40}$ structure, in which multiple factions govern the legal consequences of flights over conflict zones. In reaction to such specialisation, William Jenks observed that the rule of lex specialis derogat legi generali was gaining an ever-

38 Saiga (n 31) para 90 (Dissenting Opinion Judge Ndiaye).

39 Traditionally, such 'considerations of humanity' are applied to cases where the rights of people are on one side and State obligation is on the other. However, the Enrica Lexie case presents a different situation, in which the rights of two groups of humans oppose each other and they both invoke humanitarian arguments. A distinction is carefully drawn here. See The 'Enrica Lexie' Incident (Italy $v$ India) (Provisional Measures) Order of 24 August 2015, ITLOS Reports 2015,133 . On the one hand, Italy invokes considerations of humanity to protect its marines from the alleged breaches of due process; on the other hand, India put forward humanitarian considerations to bring to trial Italians who have allegedly killed two Indians. As Judge Paik has observed, 'there are differences between the present case and those other cases, the most critical one being the difference in terms of the gravity of the offence allegedly committed by the accused': see ibid para 7 (Declaration Judge Paik).

40 On 'fragmentation', among a volume of literature, see, in particular, ILC, 'Fragmentation of International Law: Difficulties Arising from the Diversification of International Law' (1 May-11 August 2006) UN Doc A/CN.4/L.682; Matthew Craven, 'Unity, Diversity and the Fragmentation of International Law' (2003) 14 Finnish Ybk Intl L 36; Martti Koskenniemi and Päivi Leino, 'Fragmentation of International Law? Postmodern Anxieties' (2002) 15 LJIL 553; Mario Prost, 'All Shouting the Same Slogans: International Law's Unities and the Politics of Fragmentation' (2006) 17 Finnish Ybk Intl L 1; Sahib Singh, 'The Potential of International Law: Fragmentation and Ethics' (2011) 24 LJIL 23. 
increasing amount of attention. ${ }^{41}$ The normative distinction between general and special laws is important in maintaining a systematic reconciliation. In principle, the special secondary rules of the regime will prevail. ${ }^{42}$

However, a problem with the lex specialis principle is that it is based on a particular fiction of unified State conduct-the presumption that States act with a unified legislative will when they conclude treaties or enact customary rules. ${ }^{43}$ Yet the reality is, far from reflecting the ideal presentation of unified legislative intent, treaty negotiations of air law and humanitarian law fall within the competences of two different domestic ministries-civil aviation authorities and ministry of defence respectively. Unfortunately, the communication between the two systems is limited. ${ }^{44}$

Moreover, as Martti Koskenniemi noted in his 2006 Preliminary Report for the International Law Commission, the creation of a new international norm may not be as thoughtful a process as legal theory suggests, since 'there is no single legislative will behind international law. ${ }^{45}$ Treaties and customs come about as a result of conflicting motives and objectives-they are 'bargains' and 'package-deals' and often result from spontaneous reactions to events in the environment. ${ }^{46}$ In the face of competing secondary rules and/or general international law governing the same issue, a further question is whether such an exclusion of competing norms is in fact intended by that specialised regime in question. In short, there is no objective or neutral approach to issues of fragmentation. In turn, 'whether this question is answered in the affirmative [...] may depend on whether international

Wilfred Jenks, 'The Conflict of Law-Making Treaties' (1953) 30 BYIL 401, 405; Bruno Simma, 'Self-Contained Regimes' (1985) XVI Netherlands Ybk Intl L 111; Heinrich Wilting von Wilhelm, Vertragskonkurrenz im Volkerrecht (Carl Heymans Verlag 1996); See also the International Law Commission's treatment of the notion of lex specialis, Martti Koskenniemi, 'Study on the Function and Scope of the lex specialis Rule and the Question of "Self-Contained Regimes"' (2004) Preliminary Report by the Chairman of the Study Group submitted for consideration during the 2004 session of the International Law Commission, Doc. ILC(LVI) SG/FIL/CRD.1 and Add. 1, available from the Codification Division of the UN Office of Legal Affairs. Bruno Simma and Dirk Pulkowski, 'Of Planets and the Universe: Self-contained Regimes in International Law' (2006) 17 EJIL 483, 485. ibid 489.

44 See (n 61) below.

45 ILC, 'Fragmentation of International Law' (n 40) para 34.

46 ibid. 
law is conceived as a unified legal order or as the sum total of loosely interrelated subsystems. ${ }^{47}$

According to ILC Article 55, which is based on an interpretation of international law shared by many esteemed lawyers, international law is a unified and, to a certain extent, hierarchical legal order. ${ }^{48}$ 'L'unité de lordre juridique', as Pierre-Marie Dupuy named his General Course at the Hague Academy, ${ }^{49}$ is a sociological fact or, at least, a normative postulate. ${ }^{50}$ Mireille Delmas-Marty stated that unity is an inherent characteristic of law, since '[1]aw does not like multiplicity; it represents order, unified through hierarchy and symbolized by Kelsen's pyramid of norms, built for eternity—not by clouds, even if they are organised. ${ }^{51}$

For the sake of legal clarity and certainty, unity requires normative reconciliation. As Judge Simma and Dr. Pulkowski have noted, '[i]t would be too simple, however, to assert that a fallback on general international law follows "automatically" from a mechanical application of the lex specialis maxim. Rather, normative considerations are ultimately decisive. ${ }^{52}$ In this case, there are two competing lex specialis regimes. The Chicago Convention is lex specialis in terms of aviation, while the Geneva Conventions are also a specific regime regarding armed conflicts. This presents that the use of the permitted airspace over conflict zones could produce consequences of such an inhumane nature as to clash with the basic principles of humanitarian law.

The international community thus cannot avoid having to understand how such secondary rules concerning airspace management relate to another system of international humanitarian law and the general international law. To answer this question, Judge Simma argued that '[a]s a consequence of relying on a presumption

48 ILC, 'Report of the International Law Commission on the Work of its 53rd Session' (23 April-10 August 2001) UN Doc A/56/10 paras 356-59.

49 Pierre-Marie Dupuy, 'L’unité de l'Ordre Juridique International' (2002) 297 Recueil des Cours de l'Académie de Droit International 9. See also Simma and Pulkowski (n 42) 485.

50 Similarly, Karl Zemanek, 'The Legal Foundations of the International System' (1997) 266 Recueil des Cours de l'Académie de Droit International 62. See text to (n 54) et seq of this article.

51 Mireille Delmas-Marty, Global Law: A Triple Challenge (Naomi Norberg tr, Transnational Publishers 2003) 74. The original text is as follows: '[l]e droit a l'horreur du multiple. Sa vocation c'est l'ordre unifié et hierarchisé, unifié parce que hierarchisé. Et l'image qui vient à l'esprit des juristes, c'est la pyramide des normes, construite pour léternité, plutôt que celle des nuages, fussent-ils ordonnées'. See Mireille Delmas-Marty, Trois défis pour un droit mondial (Seuil 1998) 104 (translated in Simma and Pulkowski (n 42) 495).

52 
in favour of completeness, the threshold for resorting to rules outside the regime should be much higher. ${ }^{53}$ Following this line of thought, in considering air law cases, reference to another regime needs to be sustained by special justification. That is to say, international humanitarian law does not generally offer gap-filling options, which would automatically supplement air law. Rather, humanitarian law only applies in exceptional cases, to the extent that two such specific regimes may overlap and contradict each other. Therefore, it is imperative to examine the justification for possible harmonisation.

\subsection{Harmonisation-a clarification of the law}

Despite discussing the difficulties regarding the lex specialis doctrine caused by the fragmentation of international law, this paper will now try to harmonise air law with humanitarian law. The issue is not whether one discipline pre-empts another, but whether the obligations arising from the humanitarian law regime can also be applied in the context of airspace management during armed conflicts.

\subsubsection{Renvoi}

The aforementioned perceptions and approaches, promising the very basis of a unified international legal system, call for a careful examination of the context of the aviation treaty. The first justification for harmonisation lies in Article 89 of the Chicago Convention. According to Article 89, the provisions of the Convention shall not affect States' conduct in case of war and national emergency. ${ }^{54}$ Among several possible constructions, the principle of effective interpretation ${ }^{55}$ requires

ibid 505 .

54 See Article 89 of the Chicago Convention.

55 Judge Simma states: ' $[\mathrm{t}$ ] aking the Vienna Convention on the Law of Treaties as a starting point, the effectiveness principle (or the maxim ut res magis valeat quam pereat) is reflected either in the duty to interpret "in the light of [a treaty's] object and purpose" or in the notion of good faith. The notion of good faith may be the more convincing solution: the principle of effective interpretation precludes a state from frustrating the obligations assumed by invoking a formal circumvention of the conditions under which the norm would apply'. Simma and Pulkowski (n 42) 508; cf Ian Sinclair, The Vienna Convention on the Law of Treaties (2nd edn, Manchester UP 1984) 115; Robert Jennings and Arthur Watts, Oppenheim's International Law (9th edn, Longman 1992) 1280. 
the adoption of the perspective that best gives effect to the norm in question. Article 89 expressly states that a war does not entail the obligation to notify the ICAO Council, whereas only a national emergency does. ${ }^{56}$ Such differentiation invites a comprehensive clarification of the international law corpus.

When considering the term 'war', it is notable to highlight that the Chicago Convention was drafted in 1944 whilst the Second World War was still ongoing. Once the War had ended, it was agreed that the legal translation of war should be 'armed conflict. ${ }^{57}$ Consequently, this article can be interpreted as a 'renvoi', which now leads to another set of rules applicable to armed conflicts-humanitarian law. It is the use of force in a warlike manner that defines the applicability of humanitarian law. Whether the parties to the conflict recognise themselves as being at war or not is irrelevant. ${ }^{58}$ Therefore, even if a State did not declare war or notify ICAO Council, but was undoubtedly participating in hostilities, it is legally engaged in 'armed conflict' and humanitarian rules apply automatically. This interpretation confirms the rationale of Article 89, where, in a state of war, there is no need to notify the ICAO Council. This construal of Article 89 links the Chicago Convention with the international humanitarian law applicable to armed conflicts. This approach is also supported by ICAO diplomatic conferences. ${ }^{59}$ The acceptance

There have been some cases where States have notified ICAO of a state of emergency in their countries. In these situations, States have proclaimed that under Article 89 of the Chicago Convention, they were not able to comply with their obligations under the Convention. These cases include Honduras in 1957, India in 1962, Pakistan in 1965, Pakistan and India in 1971, and Iraq in 1973. See ICAO, 'Special Group to Review the Application of ICAO Treaties Relating to Conflict Zones' (26 June 2015) SGRIT-CZ/1-WP/1, para 2.7.

57 International Committee of the Red Cross, 'How is the Term "Armed Conflict" Defined in International Humanitarian Law?' (ICRC Opinion Paper, March 2008) <https://www.icrc.org/ eng/assets/files/other/opinion-paper-armed-conflict.pdf> accessed 28 April 2015; See also the International Law Association Committee on the Use of Force, 'Initial Report on the Meaning of Armed Conflict in International Law' (ILA, 2008) <http://www.ila-hq.org/en/committees/ index.cfm/cid/1022> accessed 28 April 2015; Mary Ellen O'Connell, 'Defining Armed Conflict' (2009) 13 JCSL 393.

58 ibid.

59 During ICAO Special Group's Meeting on Reviewing the Application of ICAO Treaties Relating to Conflict Zones in Montreal from 13 to 15 July 2015, the consensus was that Article 89 is in fact two Articles consolidated into one. In 1944 (during the Second World War) there existed two bodies of laws: those that applied to peace and those that applied to war. States involved in war, the 'belligerents', would notify the fact to the 'neutral' States so that they could exercise their rights and obligations, including those associated with aviation. However, today the division between the two bodies of law is completely different, having evolved into the law applied to armed conflicts. Given that Article 89 does not provide an answer to the very 
of Article 89 confirms and reinforces the solid reasoning upon which the treaty is based. This article could not have been included in the Chicago Convention without the acknowledgement that there would be circumstances in which war rules would prevail over the Chicago Convention.

When the Chicago Convention was drafted, the main purpose of it was to promote the prosperity of the budding aviation industry. The interpretation held by this paper regarding the drafters' intention is that, in 1944, States' delegations proposed to open as large an airspace as possible, as well as taking into account that war norms would be more appropriate to deal with possible restrictions of airspace. This interpretation is reified by a consensus in ICAO's conference in $2015 .^{60}$ Due to the background of the present case, armed conflicts, war norms and other legal documents should also be applicable to the situation, alongside the Chicago Convention. As a result, Article 9 of the Chicago Convention, which allows States the choice to close their airspace, is not a complete statement.

It is also important to note that the Chicago Convention was designed to regulate 'civil' aviation during peace time. Until the advent of armed conflicts, it was thought that, however differently States may manage their airspace, the territorial government could still control and guarantee the safety of their air paths. Whereas in the case of armed conflicts, a different situation is reached in that the de facto control of the airspace is lost. Therefore, the Chicago Convention does not cover the loss of control over its airspace because of armed conflicts. Neither does it expressly prohibit, nor permit, airspace to be left open during armed conflicts. Violation of international law per se, whether by treaty or custom, does not become lawful simply because it is undertaken within the context of aviation under the Chicago Convention.

The fact that States went through the cumbersome multilateral treaty-making process to draft out Article 89 suggests that this article is of particular importance. It goes without saying that States included this special norm of international law precisely with a view to bridge the divide between air law and international

diverse scenarios of armed conflicts, this delegation posited that the legal answer may have to be sought in other bodies dealing with international law as applied to armed conflicts. ICAO, 'Special Group to Review the Application of ICAO Treaties Relating to Conflict Zones' (18 September 2015) SGRIT-CZ/1 Draft Report, paras 7.13-7.14.

60 ICAO, 'Special Group to Review the Application of ICAO Treaties Relating to Conflict Zones' (18 September 2015) SGRIT-CZ/1 Draft Report, para 2.15. 
humanitarian law. With this clear indication, we should not presume that States are unwilling to live up to their commitments regarding armed conflicts in the aviation field.

Article 89 could therefore be seen as foreshadowing a future arrangement regarding the use of airspace in armed conflicts in the form of a renvoi provision. This emphasises the need to break away from the peace-aligned legislation and go beyond the literal interpretation of Article 9 of the Chicago Convention.

In the light of the aforementioned, it can be concluded that the most directly relevant and applicable law governing this specific question is that which relates to precautionary measures within armed conflicts, particularly those which regulate the conduct of hostilities. It may now be safely concluded that the drafters of the Chicago Convention and the 191 contracting states do not hesitate to pursue the 'unity' of international law, especially when rules outside the regime appear to better serve the safety priority of the aviation legal system. Air law therefore cannot be considered to be fully comprehensive in and of itself. It may be compelled to readjust its attitudes and face the new reality by collaborating with humanitarian rules.

\subsubsection{Application to aviation}

In order correctly to apply the law to the present case, this section begins with some characteristics of aviation, and in particular, the nature of international transportation. As a sui generis organisation specialised in aviation regulation, ICAO regulates international civil aviation relations with its own dispute resolution mechanisms. ${ }^{61}$ In practice, most aviation disputes are resolved through negotiation, and, depending on the relative strength of the aviation trading partners, unilateral coercion. ${ }^{62}$ Thus, the substance of air law interacts infrequently with other international law rules.

61 Chapter XVIII of the 1944 Chicago Convention authorised the Council of the ICAO to decide upon any dispute concerning the interpretation of the Convention. See Peter Haanappel, The Law and Policy of Air Space and Outer Space: A Comparative Approach (Kluwer 2003) 17. In practice, State delegations to ICAO treaty-drafting conferences are mostly comprised of aviation professionals. Military personnel or humanitarian law experts rarely get involved.

62 At the time of writing, only six aviation disputes have been submitted to arbitration, five have been submitted to the ICAO for adjudication, and twelve have been filed with the ICJ. See Paul Dempsey, 'Flights of Fancy and Flights of Fury: Arbitration and Adjudication of 


\subsubsection{Sovereignty concern}

As discussed, Article 9 of the Chicago Convention may not in itself limit the carte blanche of States in managing its airspace in all circumstances. Certain States have in diplomatic conferences suggested the use of airspace be examined in the light of sovereignty. They contended that precautionary measures, if they exist, are subject to the sovereignty principle, and States have full freedom regarding their airspace. ${ }^{63}$ According to this view, there is a legal paradox revealing that the full competency of a State could even prevail over international law per se. To accept that States have absolute freedom in their airspace usage is tantamount to recognising that military activities can be undertaken without any constraint in all circumstances.

It is not necessary to embark upon the voluminous discussion of sovereignty, ${ }^{64}$ which is not in favour of such assertion either; ${ }^{65}$ instead it suffices to note that the very purpose of aviation is to connect geographically distant countries together via safe and reliable flights. Since its inception, aviation has imbued the public mind with feelings of amazement accompanied by an exaggerated fear regarding its

Commercial and Political Disputes in International Aviation' (2004) $32 \mathrm{Ga}$ J Intl \& Comp L 231, 304-05; Dimitri Maniatis, 'Conflict in the Skies: The Settlement of International Aviation Disputes' (1995) 20 Annals Air \& Space Law 185; Jon Bae, 'Review of the Dispute Settlement Mechanism Under the International Civil Aviation Organization: Contradiction of Political Body Adjudication' (2013) $4 \mathrm{~J}$ Intl Dispute Settlement 65.

63 ICAO, 'Special Group to Review the Application of ICAO Treaties Relating to Conflict Zones' (26 June 2015) SGRIT-CZ/1-WP/1; ICAO Legal Committee, 'The Report of the 36th Session of the Legal' (4 December 2015) LC36-WP/9-1, paras 8.4-8.9.

64 The connotation of sovereignty, which not only has a negative side but also a positive side, is to assure the minimum of protection established by international law, as put forward by Max Huber in Island of Palmas. See Island of Palmas (Netherlands v USA) (1928) II RIAA 829, 839. Further, in the Lotus case, Judge Moore stated that '[i]t is well settled that a State is bound to use due diligence to prevent the commission within its dominions of criminal acts against another nation or its people. Therefore, the exclusive competence of a State over its territory is subject to the limitation established by international law. See also Judge Moore's dissenting opinion in Lotus (France v Turkey) (1927) PCIJ Rep Series A No 10, 88.

65 For further discussion of the development of State sovereignty in airspace, see Myres McDougal, Harold Lasswell and Ivan Vlasic, Law and Public Order in Space (Yale UP 1963) 257-67; David Johnson, Rights in Airspace (Manchester UP 1965) 23-24; Ivan Vlasic (ed), Explorations in Aerospace Law: Selected Essays by John Cobb Cooper, 1946-1966 (McGill UP 1968) 55-136; Albert Moon, 'A Look at Airspace Sovereignty' (1963) 29 J Air L \& Commerce 328; Jacob Denaro, “States” Jurisdiction in Aerospace Under International Law' (1970) 36 J Air L \& Commerce 688; Robert Jennings, 'International Civil Aviation and the Law' (1945) 22 BYIL 191; Farooq Hassan, 'The Shooting Dawn of Korean Airlines Flight 007 by the USSR and the Future of Air Safety for Passengers' (1984) 33 ICLQ 712, 714. 
associated dangers. ${ }^{66}$ In response to these latter concerns, States have made safety and security a priority of global regulation. States have surrendered their sovereign authority over the subject to an extent far beyond that which has been done in other fields of international law. ${ }^{67}$

It would create a dilemma if international air law, a system intended to promote aviation safety and security, should have a place that could allow for the total destruction of a civil aircraft without impunity. A factor concealing this contradiction is the use of euphemistic language to divert attention from the loss of hundreds of innocent passengers, who then become reduced to diplomatic expressions, such as 'collateral damage. Clinically detached from their human context, euphemistic terms bypass the sphere of human suffering, out of which humanitarian law has sprung. ${ }^{68}$ Consequently, the present problem is not an abstract, purely intellectual topic which can be pursued in a spirit of scholarly detachment from the cruel realities that lie at the very core of the issue. Far from being mere exercises in logic and black-letter law, such realities cannot be logically or intellectually disentangled from their terrible context. ${ }^{69}$ Distasteful though it may be to contemplate the brutalities surrounding these legal questions, this issue can only be squarely addressed when those brutalities are brought into vivid focus. ${ }^{70}$

\subsubsection{The reality of suffering}

The sufferings of innocent passengers from a third State tend to be hidden behind a veil of generalities and platitudes. As such, aviation is unique in that, by itself it has special risks from the very beginning and States retain their final say nonetheless. A close and straightforward picture is required of the actual brutalities involved, and of the manifold threats to aviation. Given the exceedingly difficult issues that arise in applying the Chicago Convention as well as the plethora of legislation applicable in armed conflicts, it is vital to consider one further aspect of the question-a broader context.

66

67

68

69

70

Brian Havel and Gabriel Sanchez, The Principles and Practice of International Aviation Law (CUP 2014) 173-75.

ibid 176-216.

8 This aspect is touched upon in a volume of contemporary philosophical explorations of the problem of war. See Nuclear Weapons (n 5) 451 (Dissenting Opinion Judge Weeramantry). ibid 444 .

ibid. 
At present, there are 13 States suffering from armed conflicts. ${ }^{71}$ Maybe our mind is numbed by such abstract figures and cannot comprehend them. The graphically concrete description would be '[d] ozens of passenger planes are still flying over war zones and conflict areas (...) on a daily basis. ${ }^{72}$ As aviation naturally needs to traverse great areas, it is highly probable that thousands of people fly over conflict zones that are left open by the territorial State every day. As clarified in the first section, ${ }^{73}$ the ultimate power should rest in the public sphere. The improper use of this airspace will affect the credibility of international air transportation and thus may damage the industry.

In the long run, international air law, and the stability of the international aviation relations which it is intended to govern, are bound to suffer from the continuing difference of views with regard to the use of airspace over conflict zones. It is consequently important to put an end to this situation: the establishment of the long-waited precautionary measures appear to be the most appropriate means of achieving that goal. As a result, humanitarian principles could then respond appropriately and clarify the ambiguity caused by the fragmentation of international law. The ICJ in their Legality of the Threat or Use of Nuclear Weapons Advisory Opinion said:

The extensive codification of humanitarian law and the extent of the accession to the resultant treaties, as well as the fact that the denunciation clauses that existed in

International Civil Aviation Organisation, Conflict Zone Information Repository <http:// www.icao.int/czir/Pages/posts.aspx?state=default $>$ accessed 14 May 2016; Uppsala Universitet, UCDP/PRIO Armed Conflict Dataset <http://www.pcr.uu.se/research/ucdp/datasets/ucdp_ prio_armed_conflict_dataset> accessed 1 May 2016; Council on Foreign Relations, Global Conflict Tracker <http://www.cfr.org/global/global-conflict-tracker/p32137\#!/> accessed 10 May 2016; The International Institute for Strategic Studies, Armed Conflict Database $<$ https://acd.iiss.org> accessed 10 May 2016; European Aviation Safety Agency, 'List of Safety Information' (Cologne, 14 May 2016) <http://ad.easa.europa.eu/sib-docs/page-1> accessed 14 May 2016.

72 Janene Pieters, 'Passenger Jets Still Flying Over Conflict Zones' (NL Times, 14 July 2015) $<$ http://www.nltimes.nl/2015/07/14/passenger-jets-still-flying-over-conflict-zones> accessed 5 May 2016; Arguably, not all armed conflicts could affect air space and some conflicts present no missile capability so far. However, the MH17 accident was also considered astonishing in that the conflict should expand to airspace above the flight level 320. See Dutch Safety Board, Crash of Malaysia Airlines flight MH17 (The Hague, October 2015) <http://www.safetyboard. $\mathrm{nl}>$ accessed 15 May 2016. A full examination of risk assessment and management is beyond the scope of the normality discussion this paper hopes to offer. See text to $n 10$. 
the codification instruments have never been used, have provided the international community with a corpus of treaty rules $(\ldots) .^{74}$

The great majority of these treaty rules have already become customary and have reflected the most universally recognised humanitarian principles. ${ }^{75}$ These rules indicate the normal conduct and behaviour expected of States.

The conscience of the international community has also responded accordingly in the Security Council Resolution, ${ }^{76}$ with the sufficiently demonstrated collective will to eliminate such external risk to civil aviation. It does not hold back in a fashion of ivory-tower detachment, drawing its conclusions from sophisticated exercises in legal logic. In reality, common people took note of the conclusion that ultimate power rests on private entities with dissatisfaction in Dutch Parliament Hearing on 22 January 2016. ${ }^{77}$ The fact testifies to a growing awareness of the need to liberate the aviation industry and passengers from dangers, especially those resulting from the misunderstanding that unsafe airspace can nonetheless be utilised. This misinterpretation fails to comprehend established international law rules on combating risks from conflict zones.

If this liberation is not achieved, how many more civil aircraft will need to be destroyed over conflict zones in order to awaken the international community's sense of responsibility. Safety is not a zero-sum game where the adoption of certain rules would provide benefits to the airlines of some States while posing threats to the carriers of others. ${ }^{78}$ It is beneficial to all States to enhance aviation safety and security by surrendering authority over safety regulation and conforming to a universally applicable set of standards and practices.

\section{Some special European aspects}

After clarifying the legal norms with respect to the use of airspace, this paper will now raise some financial and institutional concerns of practice. By implementing national legislation and regulation consistent with the Chicago Convention and

$74 \quad$ Nuclear Weapons (n 5) para 82.

75 ibid.

76 UNSC Res 2166, UN Doc S/RES/2166 (21 July 2014).

77 Tweede Kamer der Staten-Generaal, MH17 Hoorzitting, Beleidsreactie Onderzoeksrapporten over MH17, <https://www.tweedekamer.nl/vergaderingen/commissievergaderingen/ details?id=2015A05483> accessed 14 May 2016. Havel and Sanchez (n 66) 175. 
its Annexes, air traffic management (ATM) in Europe have traditionally been regulated at a global level. ${ }^{79}$ However, a new level of ATM regulation was developed in Europe in the 1960s through the establishment of the European Organisation for the Safety of Air Navigation (Eurocontrol) ${ }^{80}$ and more recently, the European Union (EU). ${ }^{81}$

The provisions of ATM have traditionally been in the domain of public power. Pursuant to Article 28 of the Chicago Convention, mentioned above, these services have been organised and implemented by the relevant public entities, for instance, ministries of transport and civil aviation authorities. In essentially the same way as with private railways and power plants etc, some European States have corporatised or privatised their provision of air traffic management services for financial reasons. ${ }^{82}$ The service provision in these States has been separated from the national public administration with the purpose of better responding to the needs of airspace users in order to provide safe, quality and cost-effective services without unduly delays. ${ }^{83}$ It is predicted that commercially oriented management service providers will be able better to carry out such functions with minimal expenditure.

With this background in view, a practical concern regarding the (partial) closure of airspace is that such precautionary measures may reduce considerable en-route traffic. It can deprive a private service provider of a substantial part of its financial income and the economic loss cannot be compensated from the State under the current legal framework. Additionally, regarding the sharing of intelligence, it was argued that the competency of the European Common

80 EUROCONTROL is an intergovernmental organisation with 41 State parties committed to building, together with its partners, a Single European Sky that will deliver the air traffic management (ATM) performance required for the twenty-first century and beyond.

By adopting the initiative of the Single European Sky (SES) in 2004, EU has obtained legislative competence in the field of ATM and has been prompting an in-depth reform of ATM in Europe at the Pan-European level. See Regulation (EC) No 549/2004; Regulation (EC) No 550/2004; Regulation (EC) No 551/2004; Regulation (EC) No 552/2004; For a detailed elaboration of SES, see Calleja Crespo and Mendes de Leon ( $n$ 7). The term 'pan-European' was used to draw a line between EU member States and that of Eurocontrol.

82 Government Accountability Office, 'Air Traffic Control: Preliminary Observations on Commercialized Air Navigation Service Providers' <http://www.gao.gov/assets/120/111542. pdf $>$ accessed 4 May 2015.

83 ibid. Another strong financial motivation has been the viability for States to transfer financial liabilities associated with the provision of air navigation services to corporate or private entities. 
Transport Policy is presently mixed, rather than exclusive to the EU. ${ }^{84}$ It could be worthwhile to discuss whether safety and security issues, particularly the airspace management policy, should be harmonised by the EU.

Currently, the European Aviation Safety Agency (EASA) ${ }^{85}$ disseminates recommendations concerning conflict zones on behalf of both EASA and the Eurocontrol Network Manager in the form of Safety Information Bulletins (SIB) to European national aviation authorities and aircraft operators. ${ }^{86}$

Some are of the opinion that the present European institutional structures would not allow for a US FAA-type system to be put in place. ${ }^{87}$ The most important difficulty would be created by the absence of a true supranational regulator, ${ }^{88}$ and further complicated by the ongoing reluctance of member States to transfer sovereignty with respect to safety and security issues. Also, a further consideration is whether a possible supra-national approach in aligning and harmonising flight safety management could be realised through some other public actor. This possibility could be further examined, together with other practical methods, to discover a profound approach for mitigating risks to aviation from conflict zones.

\section{Conclusion}

The ultimate responsibility for the safe use of airspace falls upon the public power. Regarding the issue of fragmentation generally, there is no definite solution identified so far. It has to be examined on a case-by-case basis. Air law is not a hyper-specialised institution that stands with clinical detachment from the rest of international law. On this particular issue of flights over conflict zones, and on a purely normative plane, the potential conflict between air law and humanitarian law has to be reconciled by 'elementary considerations of humanity'. This Corfu Channel doctrine may present support for the application of a normative humanism

84

85 The European Aviation Safety Agency (EASA) is an agency of the European Union (EU) with regulatory and executive tasks in the field of civilian aviation safety.

86 European Aviation Safety Agency, 'Information on Conflict Zones' <https://www.easa.europa. eu/easa-and-you/air-operations/information-on-conflict-zones> accessed 1 May 2016.

87 The Federal Aviation Administration (FAA) is the national aviation authority of the United States, with powers to regulate all the aspects of American civil aviation.

88 Roderick van Dam, 'Conflict Zones in International Civil Aviation' (2015) 1 Tijdschrift voor Internationale Handel en Transportrecht 23, 30-33. 
to the regulation of international transport relations, thus maintaining the value of promoting aviation safety and security.

Novel as it is to introduce humanitarian rules into the Chicago Convention, various sources of international law support the conclusion that humanitarian law rules should be properly taken into account by governments in the implementation of activities during armed conflicts, with aviation as no exception. This clarification is also consistent with the intention of the drafters of the Chicago Convention in 1944 when incorporating Article 89. 